\title{
EXPERIMENTAL STUDY OF CONCRETE PREPARED BY WOOD ASH AND WASTEPAPER SLUDGE
}

\author{
BILAL WANI ${ }^{1} \&$ VIPASHA RISHI ${ }^{2}$ \\ ${ }^{I}$ M E Scholar, Department of Civil Engineering, Chandigarh University, Punjab \\ ${ }^{2}$ Assistant Professor, Department of Civil Engineering, Chandigarh University, Punjab
}

\begin{abstract}
A high rate of industrialization requires a high demand for construction material which produces a huge amount of carbon gases which harms the ozone layer and increases the normal temperature of the planet earth. This study is done to minimize that effect by the use of wood ash and wastepaper sludge which gives concrete an increment in the mechanical strength and also reduces the carbon emission replacing cement with a combined mix of wood ash (10\%) and paper sludge (5\%) gives a good increment of $4 \%$ in compressive strength, a $12 \%$ increment in tensile load, and an $18 \%$ increment in spilled tensile load. this replacement also reduces the cost of concrete up to 700 Rs.

KEYWORDS: Paper Sludge, Wood Ash, Conventional Concrete
\end{abstract}

Received: Jun 08, 2020; Accepted: Jun 28, 2020; Published: Sep 24, 2020; Paper Id.: IJMPERDJUN20201406

\section{INTRODUCTION}

Wood ash (WA) is the residue generated as a result of the combustion of wood and wood products (sawdust, chips, bark, etc.). Wood waste ash is the inorganic and organic residue remaining after the combustion of timber or unbleached wood fiber. Since wood is the most available renewable source of energy and environmentally friendly material, in the future days there will be an increase in the use of wood as an energy producer. Which results in, increase in the amount of wood ash generation. The incorporation of wood ash in the preparation of mortar mixes reduces the density noticeably. This can be attributed to the low specific gravity of wood ash. The inclusion of wood ash gives slightly better performance in terms of flowability compared with silica fume. The incorporation of $10 \%$ of silica fume enhances the compressive and flexural strengths of high-performance mortar (HPM) by about 18 and $20 \%$, respectively. Whereas, the use of $10 \%$ of wood ash increases the compressive and flexural strengths of HPM by about 10 and $14 \%$, respectively.

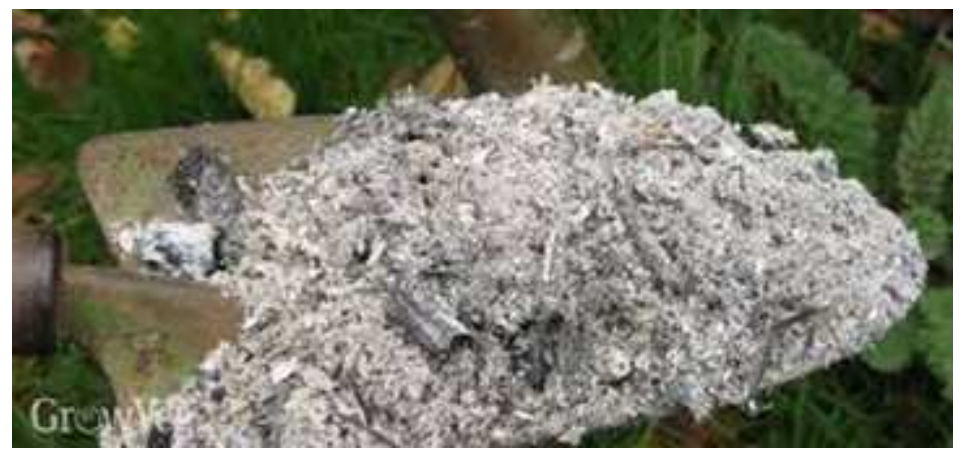

Figure 1: Wood Ash. 
These recommendations provide a solution for the waste management issues of wood waste ash and also make contributions towards minimizing the utilization of energy-intensive hydraulic cement manufacturing of greener concrete material offering the ever-growing demand of the construction industries. Wood ash has been better often called as a soil additive, but it's possible usage in cement-based materials hasn't been examined, Because of the presence of siliceous compounds and utilized in replacement of cement-like the fly ash but proper determination of chemical composition is required to serve the purpose in a better 13 manner. The presence of the compounds like $\mathrm{MgO}(0.7$ to $5 \%), \mathrm{K} 2 \mathrm{O}(0.4$ to $14 \%)$, SO3 (0.1 to $15 \%)$, TiO2 (0 to $1.5 \%)$, LOI (0.1 to 33\%), and alkali in wood ash reduces the effective utilization as a pozzolanas material and hence bringing down the line for optimum usage of wood ash.

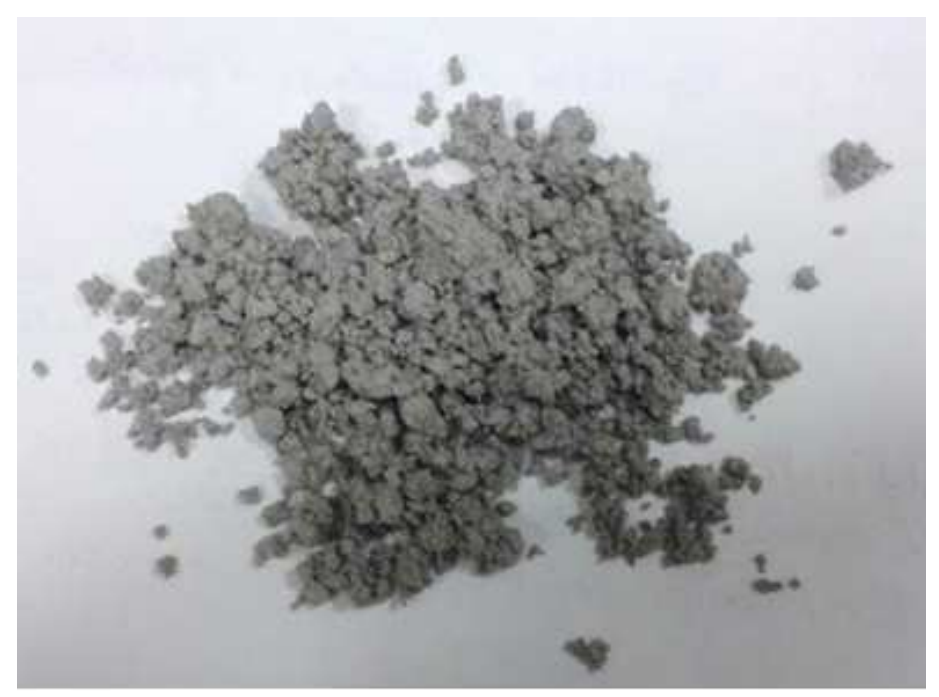

Figure 2: Paper Sludge.

Papercrete is a structure material that comprises of re-pulped paper fiber with Portland concrete or dirt or potentially other soil included. First licensed in 1928, it was restored during the 1980s. Albeit saw as a naturally benevolent material because of the huge reused content, this is balanced by the nearness of concrete. The material needs normalization, and appropriate use in this way requires care and experience. Eric Patterson and Mike McCain, who has been credited with autonomously "imagining" papercrete (they called it "PADOBE" and "sinewy concrete"), have both contributed significantly to utilizing it for building.

\section{METHODOLOGY}

For this experimental study of concrete, the following properties were determined for the production of concrete grade M25.the ratio is taken as 1:1:2 with a water-cement ratio of .45 .

- $\quad$ The specific gravity of cement - 3.15 (OPC 43 Ultratech cement).

- $\quad$ The specific gravity of Fine aggregate - 2.6 (zone II).

- The specific gravity of Coarse aggregate - 2.67 (average 20mm).

- The fineness of cement $-98 \%$.

- $\quad$ Fineness modulus of fine aggregate -3.12 .

- $\quad$ Fineness modulus of Coarse aggregate - 8.09. 
Paper sludge-1 kg wastepaper is dipped into 1-liter water for $24 \mathrm{hrs}$. After $24 \mathrm{hrs}$. Excess water removed and sludge is chopped with the trowel.

Wood ash- wood ash is taken from the burning of waste wood cramps in the wood market.

To study the different mechanical properties of the proposed concrete 4 test was done

- $\quad$ Slump test.

- Compression test.

- $\quad$ Flexure test.

- $\quad$ Split tensile test.

For these tests 5 mix ratios were considered as listed in Table 1. For each test 3 specimens are prepared for each test for each day testing i.e. after 7 days of curing and after 28 days of curing. And each time the workability is tested by a slump cone test.

Table 1: Mix Proportions for Trials

\begin{tabular}{|c|c|c|c|c|}
\hline S/No. & Mix & Paper Sludge & Wood Ash & Total Cement Replaced \\
\hline 1 & B1 & $0 \%$ & $0 \%$ & $0 \%$ \\
\hline 2 & B2 & $2 \%$ & $3 \%$ & $5 \%$ \\
\hline 3 & B3 & $3 \%$ & $6 \%$ & $9 \%$ \\
\hline 4 & B4 & $5 \%$ & $10 \%$ & $15 \%$ \\
\hline 5 & B5 & $7 \%$ & $15 \%$ & $22 \%$ \\
\hline
\end{tabular}

These different proportions were prepared and replaced against cement.

\section{RESULTS}

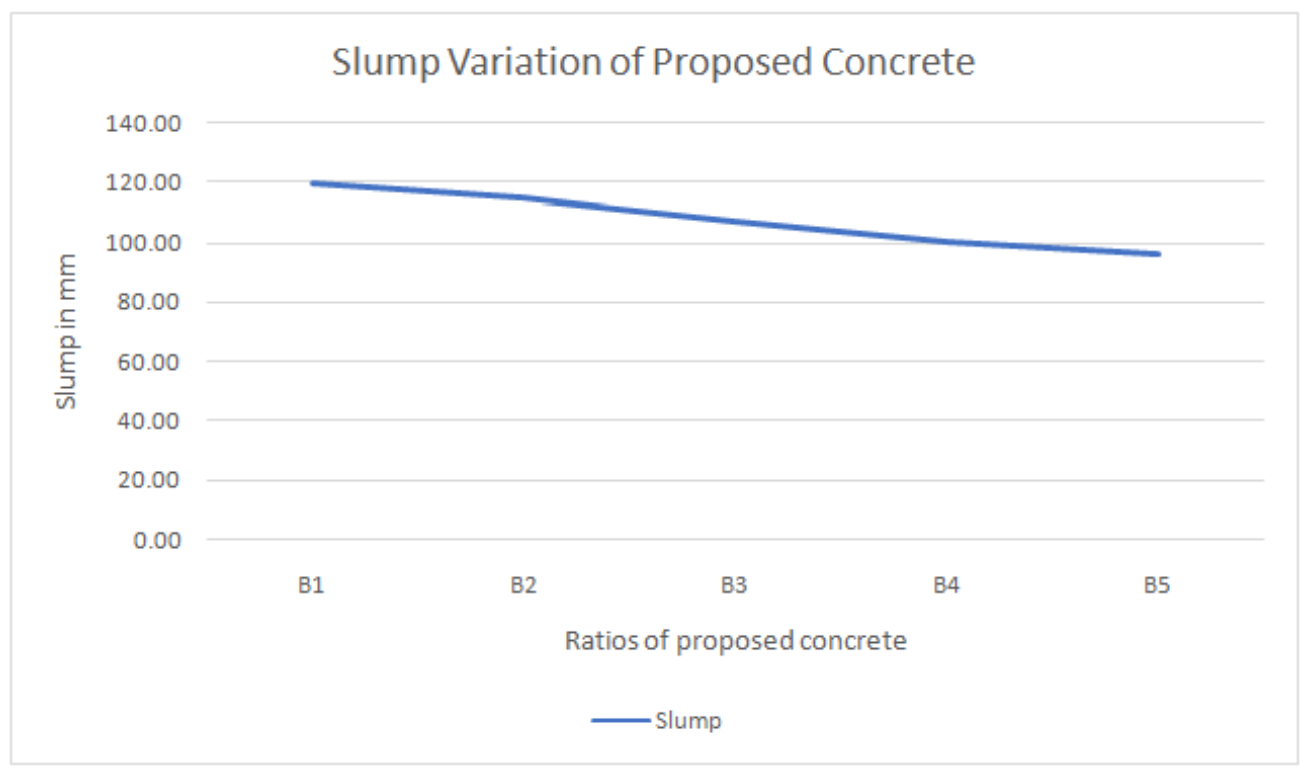

Figure 3: Results: Slump Variation of Concrete.

Wood ash generally soaks water which makes an extra water demand in the concrete which gradually affects the workability of concrete. So if there is an increase in wood ash content in concrete then workability will decrease because the ash consumes water. While the presence of paper sludge makes no impact on the concrete. 


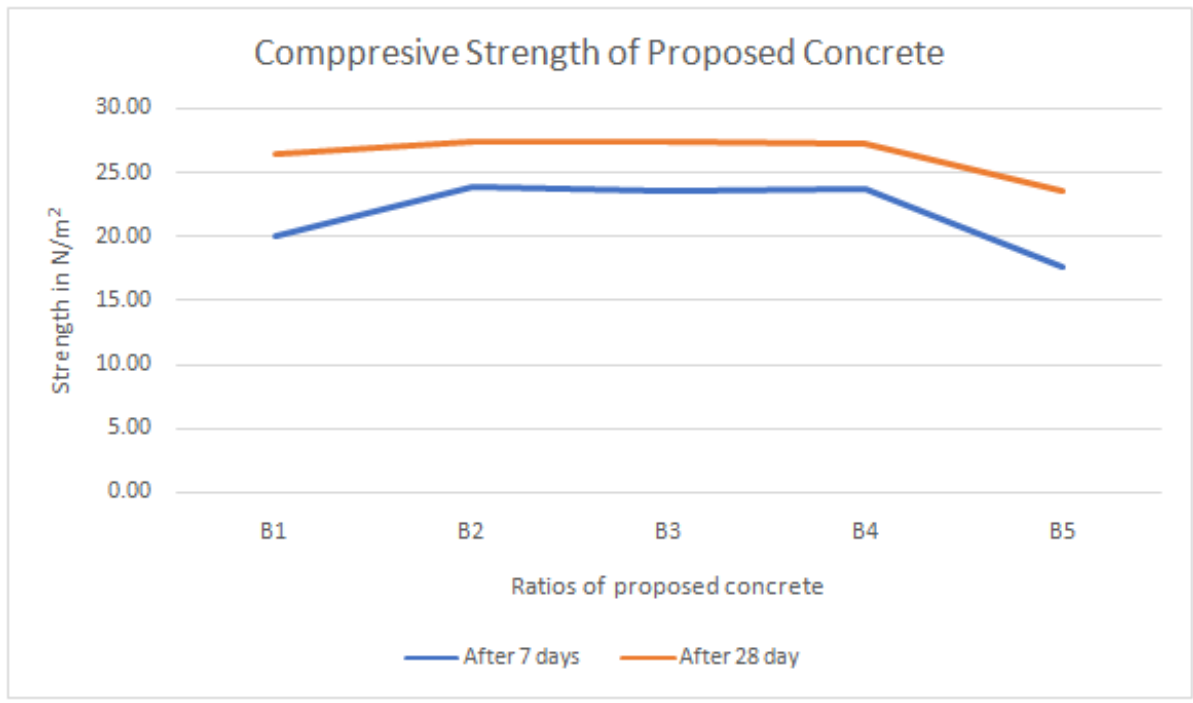

Figure 4: Results: Flexural Strength Variation of Concrete.

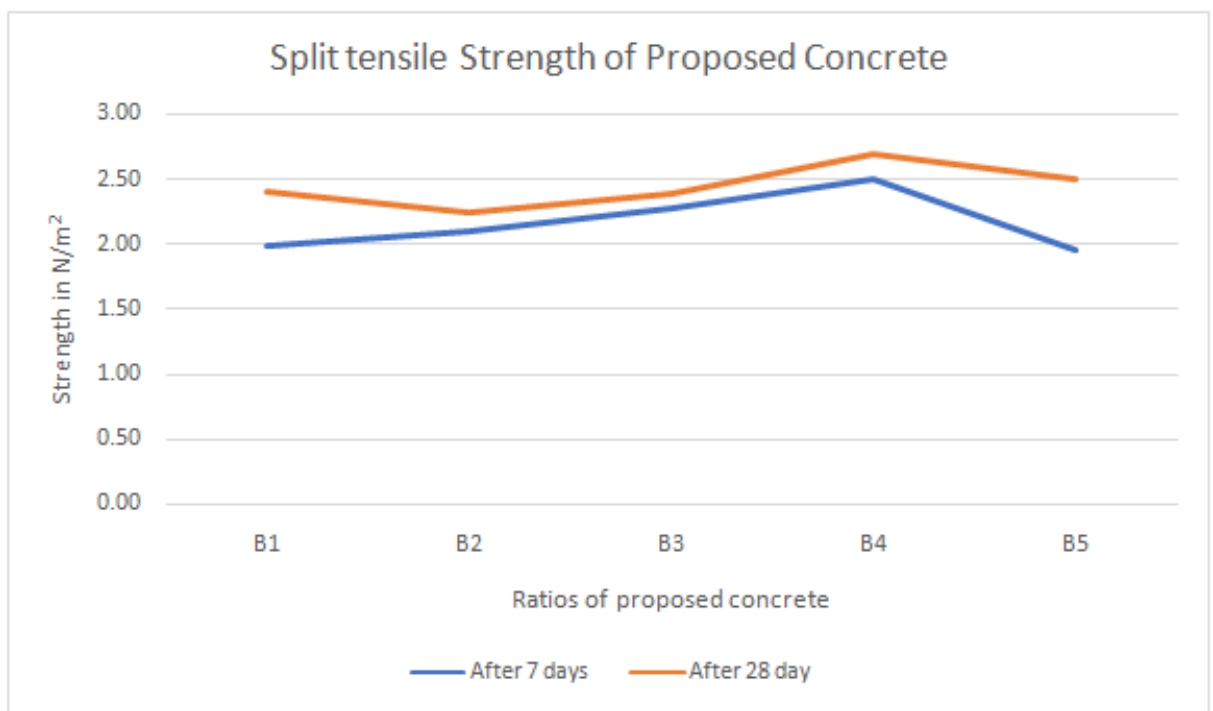

Figure 5: Results: Split Tensile Strength Variation of Concrete.

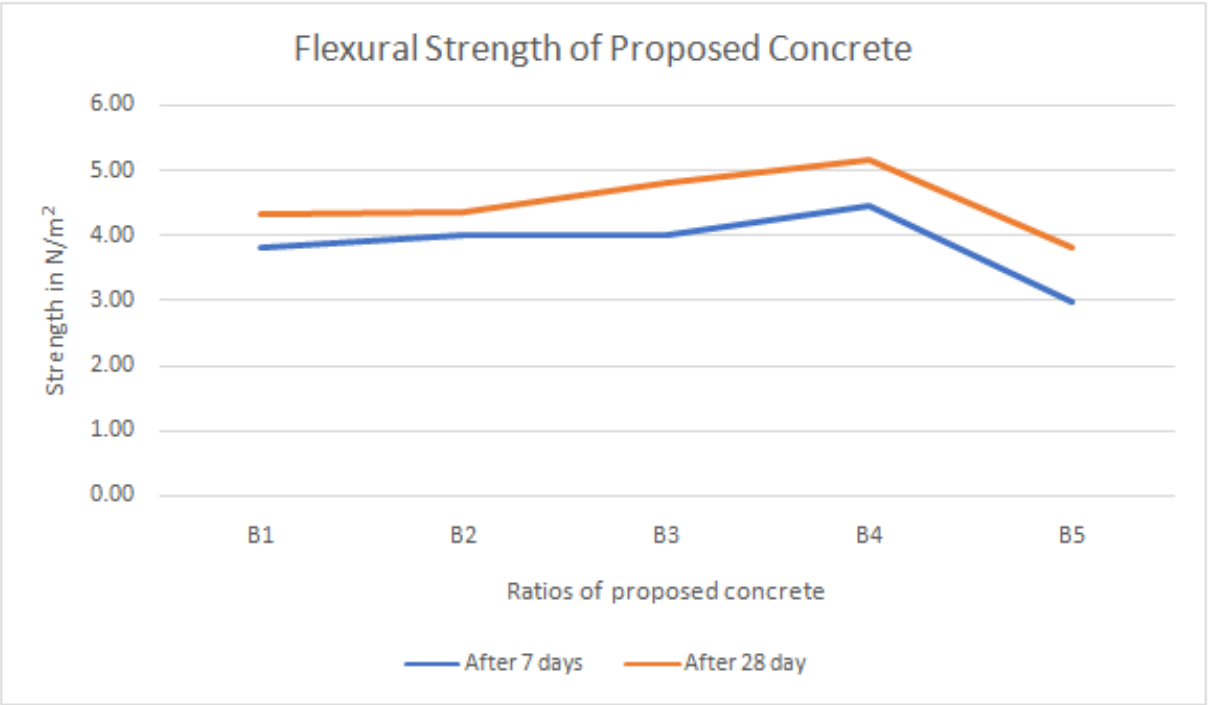

Figure 6: Results: Flexural Strength Variation of Concrete. 
Wood ash has the pozzolanic action and the main constituent of concrete is the cement which mainly works on the pozzolanic action of the concrete so adding wood ash can make increment in the compressive strength but at the same time paper sludge is also added in the concrete mix, so no much changes are seen in the compressive strength of concrete is seen. But after the excess addition of the wood ash and paper sludge, the strength decreases. Paper sludge behaves as the fibrous material which helps the concrete to increases it's flexural and split tensile strength. Hence paper is the very thin mesh of wood fibers, on mixing with water it shows more fibrous action, which results in an increment of flexure and split tensile strength.

After the optimum replacement of cement with a combined mix of wood ash and paper sludge, the cost of concrete can be decreased upto 700 Rs (in accordance with the rates of the material of April2020 in the region of Mohali, Punjab).

\section{CONCLUSIONS}

- The proposed concrete can be prepared by the proper replacement of cement with wood ash by $10 \%$ and paper sludge by $5 \%$.

- As the content of wood ash increases the workability decreases.

- Paper sludge shows fibrous action which makes a good increment in split tensile and flexural strength of concrete.

- $\quad$ The combined use of wood and paper sludge can also decrease the cost of concrete upto 700 Rs.

\section{REFERENCES}

1. Ahirwar, S. (2018) 'Effective use of Paper Sludge ( Hypo Sludge) in Concrete', International Journal of Engineering Development and Research, 6(2), pp. 677-680.

2. Ahmad, S. et al. (2015) 'Study of Concrete Involving Use of Waste Paper Sludge Ash as Partial Study of Concrete Involving Use of Waste Paper Sludge Ash as Partial Replacement of Cement', IOSR Journal of Engineering, 03(11), pp. 5-15. doi: 10.9790/3021-031130615.

3. Almeida, D. De and Zulanas, C. (2016) 'Use of contaminated sludge in concrete', Procedia Engineering. Elsevier B.V., 145(480), pp. 1201-1208. doi: 10.1016/j.proeng.2016.04.155.

4. Banevi, V. et al. (2019) 'The Possibilities of Paper Sludge Waste (PSw) Utilization in Cement Materials $\dagger$ ', in MDPI Proceedings, pp. 2-5. doi: 10.3390/proceedings2019016034.

5. Batt, A. S. and Garg, A. (2017) 'Journal of Civil \& Environmental Partial Replacement of Wood Ash with Ordinary Portland Cement and Foundry Sand as Fine Aggregate', Journal of Civil \& enviromental engineering, 7(2). doi: 10.4172/2165$784 X .1000272$.

6. Chowdhury, S., Maniar, A. and Suganya, O. M. (2015) 'Strength development in concrete with wood ash blended cement and use of soft computing models to predict strength parameters', journal of Advanced Research. Cairo University, 6, pp. 907913. doi: 10.1016/j.jare.2014.08.006.

7. Chowdhury, S., Mishra, M. and Suganya, O. (2015) 'The incorporation of wood waste ash as a partial cement replacement material for making structural grade concrete: An overview', Ain Shams Engineering Journal. Faculty of Engineering, Ain Shams University, 6(2), pp. 429-437. doi: 10.1016/j.asej.2014.11.005. 
8. Ganesan, K., Rajagopal, K. and Thangavel, K. (2007) 'Evaluation of bagasse ash as supplementary cementitious material', Cement and Concrete Composites, 29(6), pp. 515-524. doi: 10.1016/j.cemconcomp.2007.03.001.

9. IS: 456 (2000) 'Plain Reinforced Concrete- code of practice', Indian Standard.

10. IS 383: 2016 (2016) 'Coarse and fine aggregate for concrete - specification (third revision)', Indian Standard, third edit (January).

11. IS 516:1959(1959) 'Methods Of Tests For Strength Of Concrete', Indian Standard.

12. IS 5816:1999 (1999) 'splitting tensile strength of concrete- method of test', Indian Standard.

13. Kien, N., Satomi, T. and Takahashi, H. (2019) 'In fl uence of industrial by-products and waste paper sludge ash on properties of recycled aggregate concrete', Journal of Cleaner Production. Elsevier Ltd, 214, pp. 403-418. doi: 10.1016/j.jclepro.2018.12.325.

14. Kumar, G. B. R. and Kesavan, V. (2020) 'Materials Today: Proceedings Study of structural properties evaluation on coconut fiber ash mixed concrete', Materials Today: Proceedings. Elsevier Ltd., 22, pp. 811-816. doi: 10.1016/j.matpr.2019.10.158.

15. Liu, Y. et al. (2020) 'Utilization of drinking water treatment sludge in concrete paving blocks: Microstructural analysis , durability and leaching properties', Journal of Environmental Management. Elsevier Ltd, 262(March), p. 110352. doi: 10.1016/j.jenvman.2020.110352.

16. Ohenoja, K. et al. (2020) 'Direct carbonation of peat-wood fl y ash for carbon capture and utilization in construction application', Journal of CO2 Utilization. Elsevier, 40(March), p. 101203. doi: 10.1016/j.jcou.2020.101203.

17. Prabagar, S., Subasinghe, K. and Fonseka, W. R. K. (2015) 'Wood Ash as an Effective Raw Material for Concrete', International Journal of Research in Engineering and Technology, 4(February), pp. 228-233. doi: 10.15623/ijret.

18. Rabie, G. M., El-halim, H. A. and Rozaik, E. H. (2019) 'Influence of using dry and wet wastewater sludge in concrete mix on its physical and mechanical properties El-BADRASHEN WWTP', Ain Shams Engineering Journal. Faculty of Engineering, Ain Shams University, 10(4), pp. 705-712. doi: 10.1016/j.asej.2019.07.008.

19. Singh, D. and Rajesh, R. (2017) 'Experimental Study on Paper Sludge as Cement Replacement in Cement Concrete', International Journal for Scientific Research \& Development|, 5(10), pp. 243-248.

20. Varma, Y. D. and Shermale, M. B. (2015) 'Effective use of Paper Sludge ( Hypo Sludge) in Concrete', International Journal for Scientific Research \& Development, 3(8).

21. Kiran, Tsai. "Comparision of Split Tensile Strength and Flexural of Glass Fiber Reinforced Concrete with Conventional Concrete." International Journal of Civil, Structural, Environmental and Infrastructure Engineering Research and Development (IJCSEIERD) 6.2 (2016):35-42

22. Shah, Aanal, and CB Shah. "Influence of Alkaline Activators and Temperature on Strength Properties of GGBS Based Geopolymer Concrete." International Journal of Civil Engineering (IJCE) 6.3 (2017):21-28

23. Jacob, Anoop, and Nivin Philip. "A Review on High Performance Concrete." International Journal of Civil Engineering (IJCE) 4.6 (2015): 39-46. 